\title{
Effect of Public Educational Spending and Macroeconomic Uncertainty on Schooling Outcomes: Evidence from Nigeria
}

\author{
Efecto del gasto público en educación y la incertidumbre \\ macroeconómica en los resultados educacionales: \\ evidencia sobre Nigeria
}

\author{
Risikat Oladoyin S. Dauda, Ph.D. ${ }^{1}$
}

Received: April 5, 2011

Accepted: August 4, 2011

\begin{abstract}
This study examines the effect of government educational spending and macroeconomic uncertainty on schooling outcomes in Nigeria using the econometric methods of cointegration and error correction mechanism together with the vector autoregression methodology. The results indicate that schooling outcome cointegrated with all the identified explanatory variables. The study found that public educational spending impacts positively on schooling outcome while macroeconomic instability impacts negatively. The variance decomposition analysis shows that "own shocks" constitute the predominant source of variation in schooling outcome. The impulse response analysis shows that any unanticipated increase in the macroeconomic uncertainty rate will have a contractionary impact on literacy rate. The policy implication of this study is that government should pay attention to policies that enhance educational attainment through adequate public social investment under stable macroeconomic environment.
\end{abstract}

Keywords: Public spending, education expenditures, education/schooling outcomes, macroeconomic uncertainty.

\section{Resumen}

Este estudio examina el efecto en el gasto público en educación y la incertidumbre macroeconómica en los logros educacionales en Nigeria usando métodos econométricos de cointegración y mecanismos de corrección de error junto con la metodología de vector de autoregresión. Los resultados indican que los logros educacionales se cointegraron con todas las variables explicativas identificadas. El estudio encontró que el gasto público educacional impacta positivamente en los logros educativos, mientras que la inestabilidad macroeconómica impacta negativamente en estos. El análisis de la varianza de descomposición muestra que "shocks propios" constituyen la fuente predominante de variación en los logros educacionales. El análisis de respuesta de impulso muestra que un incremento no anticipado en el índice de incertidumbre macroeconómico tendrá un impacto de contracción en el índice de alfabetización. La implicancia política de este estudio es que el gobierno debería poner atención en sus políticas para mejorar el rendimiento educativo a través de un adecuado programa de inversión social pública en un ambiente macroeconómico estable.

Palabras claves: Gasto público, gasto educacional, resultados de educación/estudios, incertidumbre macroeconómica.

1. Senior Lecturer. Department of Economics, Faculty of Social Science, University of Lagos, Akoka, Lagos.<rissydauda@yahoo. com>, <rdauda@unilag.edu.ng>. 


\section{INTRODUCTION}

In the mainstream economic literature, public education expenditures have been recognized as a key aspect of fiscal outlays in most developing countries of the world. The reasons put forward in defense of government involvement in education financing are not far-fetched. Empirically, education and human capital have been found to have a positive and significant effect on economic growth (World Bank, 1980; Barro, 1998; Barro $\&$ Sala-i- Martin, 1995), reduce fertility rates (Moock \& Jamison, 1988), improve health and enhance social and political participation (Hill \& King, 1991).

According to Sen (1999), education has both intrinsic and instrumental value. It is desirable not only for the individual but also for the society as a whole. Education as private good benefits directly those who receive it, which in turn affects the individual's future income stream. At the aggregate level, a better educated workforce is thought to increase the stock of human capital in the economy and increase its productivity. Considering the externalities prevalent in education, it is widely accepted that the state has a key role to play in ensuring equitable distribution of educational opportunities to the entire population. This is particularly crucial in developing countries such as Nigeria that suffer from high levels of poverty, inequality and market imperfections. Public intervention in education can lead to improvement in the future stream of individuals, enabling equitable distribution of wealth and help reduce poverty (Mukherjee, 2007).

Furthermore, the justification of public spending on social goods, particularly education, is based on the classical literature on public goods, where it is argued that social goods provide a rationale for the allocative function of budget policy. It is argued that the public sector performs certain functions because some goods cannot be provided efficiently through the market system owing to apparent market failures or associated inefficiencies. Market failure occurs because the benefits created by social goods are not limited to one particular consumer who purchases the goods, as is the case with private goods. The non-rival or non-excludability nature of public goods has important implication for consumer behavior and on the provision of both private and social goods (Musgrave \& Musgrave, 1989). Although the market mechanism is structured for the provision of private goods, the exclusivity of the title accorded purchasers of private goods is lacking in social goods. It would be inefficient therefore to exclude any consumer from partaking in the benefits of a social good since such consumption does not reduce or limit the benefits according to others (Onwioduokit \& Tule, 2002).

In view of the foregoing, conscious attempts have been made to examine the effectiveness and efficiency of public expenditure in the social sector. A number of past studies, such as Filmer and Pritchett (1997), Mingat and Tan (1992), Harbison and Hanushek (1992), Gupta et al. (2002), Baldacci et al. (2004) among others, have investigated the effectiveness of public spending in education (and health) on social development outcomes such as enrollment rates, infant mortality rate, life expectancy and other outcome indicators. Most of these studies either use cross-country datasets or concentrate on a sub-sample of developing economies or on a particular region like Africa. The results of these cross-country studies are mixed. Harbison and Hanushek (1992), for instance, examined twelve studies in developing countries that investigated the linkages between public education spending and educational outcomes. Six of these studies establish a statistically significant positive relationship between the two; others found no evidence of any measurable impact on outcomes. This, by implication, suggests the need for an in-depth analysis of the effectiveness and efficiency of public spending in educational outcomes with a view to determining whether further gains can be achieved with better use of resources with improved quality.

Educational attainment is believed to be sensitive to macroeconomic problems resulting from negative internal and external shocks that a country has to face. These shocks include terms of trade shocks, political instability, war, policy uncertainty and other disturbances among others. Uncertainty and instability are generally believed to be serious obstacles to public social spending in developing/transition economies. Sudden 
economic downturns, resulting from factors such as fiscal weakness, weak financial systems, falling external competitiveness, a decrease in export volumes, and natural disasters are a reality in many African countries, including Nigeria.

The theory of human capital suggests that macroeconomic crises can affect the total amount of schooling attainment, the timing of this schooling, and the effort which is devoted to schoolwork. Generally, an adverse macroeconomic shock will depress major macroeconomic variables including current employment and wage prospects. Consequently, the opportunity cost of attending school will fall. Holding everything else equal, this should culminate in an increase in human capital investment. When macroeconomic shocks are persistent, they may also depress expected lifetime earnings, and have an effect on the marginal benefit from schooling. If the lifetime earnings of all individuals increased by the same percentage, regardless of their schooling, then the marginal benefit associated with an additional year of schooling will be lower. Crises need not, however, have a uniform effect across the board on expected earnings. In addition, the effect of a crisis on the wages and employment prospects of adults in a household may also have an effect on the schooling and employment decisions of children (Schady, 2002). Galor and Zeira (1993) reveal that income and wealth distributions affect the adjustment of the economy to aggregate shocks, when this adjustment calls for investment in human capital and sectorial shifts. Also, many studies have explored the complex nature of the relationship between human capital formation and child labor and found that child labor impedes the acquisition of education and human capital in developing countries. Some studies, however, find the opposite result: Basu and Van (1998) give a thorough review of studies that examined the relations between intergenerational dynamics of child labor and human capital formation.

Empirical studies on the relationship between macroeconomic uncertainties and human capital formation are scanty. The empirical evidence on the interaction between systemic shocks, educational investment and schooling outcomes is mixed. For instance, evidences abound in the literature that the United States of America experienced a large increase in secondary school enrollment rates during the Great Depression, especially in those states that were hardest hit by unemployment (Goldin, 1999). Within the context of the developing countries setting, some studies report that macroeconomic shocks have negative effects on enrollment (Flug, Spilimbergo \& Wachtenstein, 1998; Behrman, Duryea, \& Szekely (2000). These studies are mainly cross-sectional in nature which, by implication, means that the parameter estimates are similar across countries. Evidence from specific countries is rare and, specifically, studies on the effect of macroeconomic shock and public educational spending on schooling/ educational outcomes in Nigeria are few. Therefore, the main objective of this study is to examine the effect of public educational spending and macroeconomic uncertainty on schooling outcomes in Nigeria for the period from 1975 to 2007, using the econometric methods of cointegration and error correction techniques together with the vector auto-regression methodology.

The organization of the rest of the paper is as follows: section two focuses on the literature review. Section three gives an overview of the performance of Nigerian economy and educational development. Section four deals with the analytical procedure, model specification and estimation techniques, while section five presents the empirical analysis, including the policy implications of the findings. Lastly, section six summarizes the findings and also contains the concluding remarks.

\section{LITERATURE REVIEW}

There is now a substantial literature exploring the relationship between public spending on education and outcomes such as enrolment rates. However, decades of intensive studies produce conflicting results. Most of these studies are based on cross-country data. Most studies revealed that the direct impact of public investment on measures of education attainment is weak (Noss, 1991; Mingat \& Tan, 1992). Findings by Anand and Ravallion (1993) showed that there was no significant relationship between education outcomes and public 
education spending. Gupta et al. (1999) use ordinary least square and two stages least squares regression on a cross section of data from 50 developing and transitional economies. Results indicate that greater public spending on primary and secondary education has a positive impact on widely used measures of education attainment such as gross enrolment in primary and secondary education, gross enrolment in secondary education and persistence through grade four. Regression estimates showed that performance in the education sector is also affected by other factors such as per capita income, urbanization, adult illiteracy, access to safe sanitation and water, and immunization. This is consistent with the findings of Mingat and Tan (1992).

McMahon (1999) found a negative and significant relationship between per pupil expenditures and the primary gross enrolment rate, and a positive and significant impact of total education expenditure as a proportion of GNP. Findings from the McMahon study suggest that increasing primary education expenditures has a positive and significant impact on the primary gross enrolment rate. However, it is noteworthy that this study does include per capita income as an explanatory variable, and probably these resource variables might have been used as proxy for per capita income. Colclough and Lewin (1993) include per capita income variables and found that expenditure as a proportion of GNP is not significant when entered separately.

In a study of five African countries, Ogbu and Gallagher (1991), attempt to establish whether education outcome are affected by the composition of public education spending. They reported that enrolment rates are significantly affected by the composition of public education spending. Using a panel data for African countries from 1990 to 2002, the aim of Anyanwu and Erhijakpor (2007) was to investigate the relationship between government expenditure on education and enrolment at the primary and secondary school levels, with illustrations from the SANE countries (South Africa, Algeria, Nigeria and Egypt). Results provide support for the proposition that government expenditure on education impacts positively on education attainment. The evidence is stronger for secondary education. The study also finds that other policy interventions, such as consolidating and sustaining democracy, accelerating national income and international community fulfilling its aid promises to Africa also were found crucial for school enrolment. This is consistent with the findings of Mingat and Tan (1992) which reported that others variables such as per capital income, the age distribution of the population, parental perceptions of costs and benefits, urbanization and family background or parental education are statistically significant variables explaining education attainment.

A number of studies have examined the effect of macroeconomic crises on schooling outcomes. However, the link between crisis and schooling attainment seems to be ambiguous. Kisswani (2008) explores the impact of the Great Depression on education, on race (whites and blacks) and gender (males and females), during the period 1930-1940. The results (using individual census data from 1960) show some evidence that the Great Depression affected the education of white individuals born between 1911 and 1915 .

Schady (2002) analyzed the impact of macroeconomic crisis on education in Peru between 1988 and 1992. The author reported that crisis has no effect on attendance rates but noticed a significant decline in the fraction of children who are both employed and attend school. Using cross-country regressions, Flug, Spilimbergo and Wachtenstein (1998) report that macroeconomic shocks have negative effects on enrollment. Behrman, Duryea, and Szekely (2000) suggest that the poor macroeconomic prospects of the 1980's in Latin America set back the rate of growth of schooling attainment in the region. In Indonesia, Thomas et al. (2004) observed that the country's deep financial crisis of 1998 seemed to have had little effect on schooling outcomes. This is consistent with the works of Cameron (2000) and Pradhan and Sparrow (2000) which report some impact of the crisis on enrollment, although the effects tend to be small.

The message from the above review is clear. The empirical evidence on the interaction between public educational expenditure, macroeconomic shocks and 
schooling outcomes is inconclusive. Generally, it is difficult to draw policy conclusions from cross-country data; much however, depends upon the country specific situation. This is the motivation for this paper.

\section{NIGERIA: MACROECONOMIC ENVIRONMENT AND PERFORMANCE OF THE EDUCATION SECTOR}

During the late 1970s and early 1980s, Nigeria, like most developing countries, experienced unprecedented and severe economic crisis. As a result, the country lost decades of development due to negative-to-slow growth and has been one of the weakest growing economies in the world on a per capita basis especially for the period 1981-2000. Broad macroeconomic aggregates - growth, terms of trade, real exchange rate, government revenue, etc. - have proved, over the 1975-2000 period, to be some of the most volatile in comparison to over 100 developing countries. Over the last three decades, high macro volatility has become a key determinant as well as consequence of poor economic management (NPC, 2004). Table 1 and Figure 1, which provide data on selected macro and socioeconomic indicators for selected years, support this summary view. Generally, the economy has been characterized by widening saving investment gap, high variable rates of inflation, chronic balance of payments and huge budget deficits. Macro policy has been greatly circumscribed by the high/inefficient as well as highly volatile and unstable public sector spending. The extremely volatile macroeconomic environment has continued to produce adverse economic and social effects in all spheres of life.

Table 1.

Performance of Some Selected Macro and Socioeconomic Variables for Selected Years (\%)

\begin{tabular}{cccccc}
\hline Year & $\begin{array}{c}\text { Capacity } \\
\text { Utilization }\end{array}$ & $\begin{array}{c}\text { Monthly Average } \\
\text { Exchange Rate (N/\$) }\end{array}$ & $\begin{array}{c}\text { Overall Fiscal Budget } \\
\text { Deficit as a ratio of GDP }\end{array}$ & $\begin{array}{c}\text { Growth of Real } \\
\text { GDP }\end{array}$ & $\begin{array}{c}\text { Adult literacy rate } \\
\text { (\% ages 15 and above) }\end{array}$ \\
\hline 1975 & 76.6 & 0.6159 & -1.99 & 6.0 & 38.0 \\
1980 & 70.1 & 0.5464 & -3.98 & -0.8 & 39.0 \\
1985 & 38.3 & 0.8938 & -4.48 & -3.4 & 44.0 \\
1990 & 40.3 & 8.0378 & -8.27 & 8.3 & 52.0 \\
1995 & 29.29 & 21.8861 & 0.05 & 2.7 & 57.0 \\
2000 & 36.1 & 102.1052 & -2.26 & 3.8 & 57.0 \\
2005 & 54.80 & 132.1470 & -1.11 & 6.51 & 57.0 \\
2006 & 53.30 & 128.6516 & -0.55 & 6.03 & 64.2 \\
2007 & 53.38 & 125.8331 & -0.50 & 6.45 & 64.2 \\
\hline
\end{tabular}

Source: Central Bank of Nigeria 2008. Annual Report and Statement of Accounts, CBN, Abuja

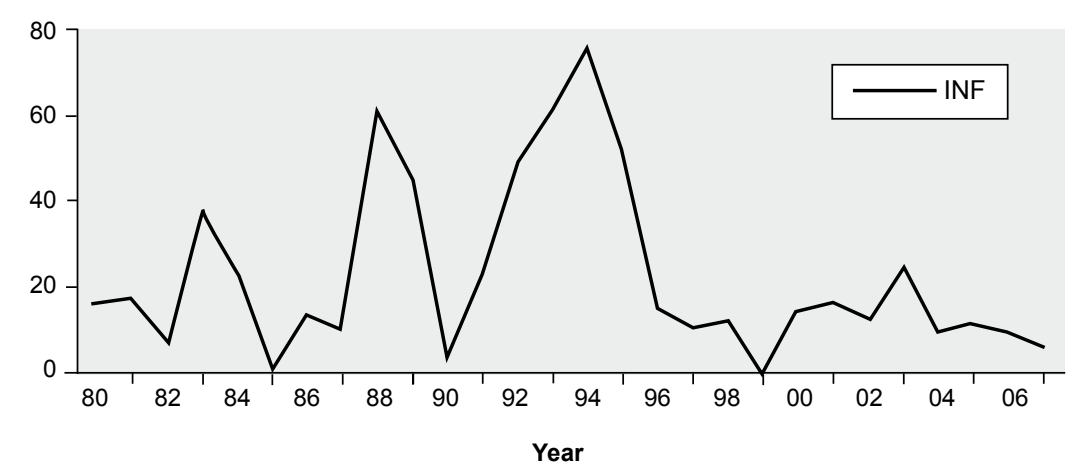

Figure 1. Inflation rate, 1980-2007 (\%).

Source: Central Bank of Nigeria 2008. Annual Report and Statement of Accounts, CBN, Abuja 
An examination of the trends in public spending on education further sheds light on the possible impact of macroeconomic instability on human-capital related sectors. Figure 2 and Table 2 show the expenditure on education as a ratio of GDP and total government expenditure. Education expenditure as a ratio of total government expenditure between 1975 and 2007 averages $6.97 \%$ and varies from $2.22 \%$ to $14.30 \%$. This fell below the minimum standard of $26 \%$ of annual budget prescribed by the United Nations Scientific and Cultural Organization. The emerging trend shows that education expenditure as a ratio of GDP follows the same trend. It ranges from $0.39 \%$ to $7.86 \%$ with a mean of $1.62 \%$. It is evident from the analysis that the Nigerian government needs to commit much greater fund to education sector if the country wants to develop skilled manpower that would make enormous contribution to growth and development.

Table 2.

Ratio of Government Expenditure on Education to GDP and Total Government Expenditure (\%)

\begin{tabular}{ccc}
\hline Year & $\begin{array}{c}\text { Educational Expenditure } \\
\text { as a ratio of GDP }\end{array}$ & $\begin{array}{c}\text { Educational Expenditure as a ratio } \\
\text { of Total Government Expenditure }\end{array}$ \\
\hline $1975-1979$ & 2.81 & 11.07 \\
$1980-1985$ & 2.00 & 8.96 \\
$1986-1992$ & 0.80 & 3.82 \\
$1993-1998$ & 0.85 & 4.91 \\
$1999-2004$ & 1.17 & 7.01 \\
$2005-2007$ & 3.22 & 7.59 \\
$1975-2007$ & 1.62 & 6.97 \\
\hline
\end{tabular}

Source: Computed by the author based on data from Central Bank of Nigeria 2008. Annual Report and Statement of Accounts, CBN, Abuja

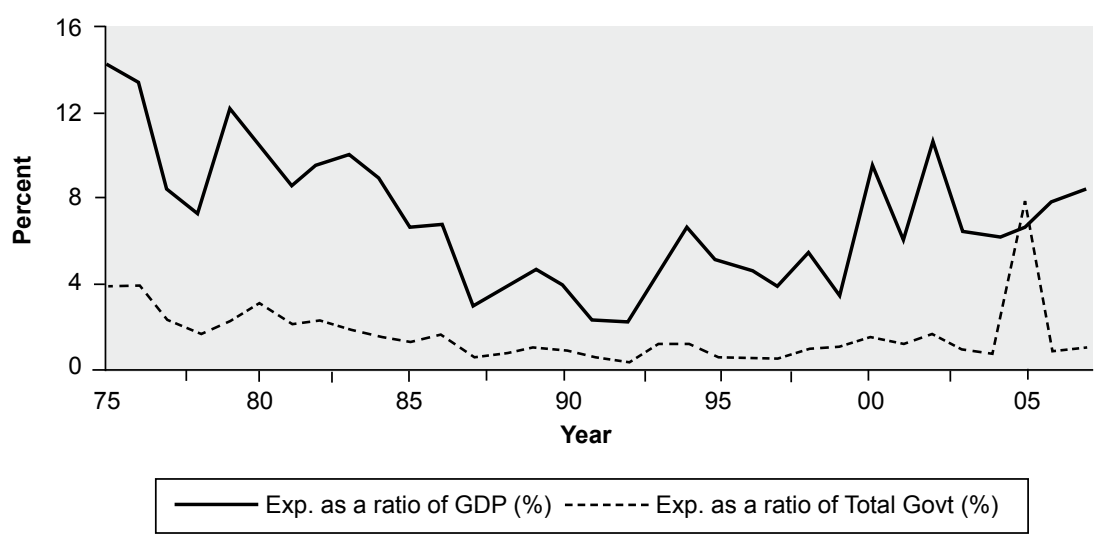

Figure 2. Expenditure on Education as a Ratio of GDP and Total Government Expenditure

Source: Computed by the author based on data from Central Bank of Nigeria 2008. Annual Report and Statement of Accounts, CBN, Abuja 


\section{ANALYTICAL PROCEDURE, MODEL AND ESTIMATION TECHNIQUES}

\section{Model Specification}

Following Gupta et al. (1999 and 2002), a general model showing the relationship between public education spending and schooling/educational outcome is developed. This model is a modified education production function which is complemented with a series of control variables introduced into the model. Generally, an education production function describes the nexus between combinations of schooling inputs, economic and non-economic inputs and the resulting output. The production process depends, in part, on the education subsystem and its resource input but also on the noneconomic, social, economic and physical conditions. The general model used by Gupta et al. (1999) is an education production function given as:

$$
Y_{t}=f\left(X_{1 t}, X_{2 t}, Z_{t}\right)
$$

where $Y_{t}$, is a social indicator reflecting education attainment for a country $t$ as measured by adult literacy rate, which is a function of aggregate public spending on education as a share of GDP, $X_{1 i}$; allocations to different programs within the sector; $X_{2 t}$; and a vector of socioeconomic variables $Z_{t}$. Following this reasoning, schooling/educational outcome is specified to depend on public educational spending as a percentage of GDP, GDP per capita, macroeconomic uncertainty and urbanization. Consequently, the following model is specified to examine the effect of public educational spending and macroeconomic uncertainty on schooling outcomes in Nigeria.

$$
L I T=f(P E X, M A U, P C I, U R B)
$$

where;

LIT: educational attainment, as measured by adult literacy rate

PEX: Public expenditure on education as a percent of GDP
MAU: Macroeconomic uncertainty (derived by percentage change in annual inflation rate, where inflation rate is based on the consumer price index

PCI: GDP per capita measured in purchasing power parity.

URB: Urban population, as a measure of urbanization

\section{$\mathrm{U}$ : Error term}

The public expenditure is expected to have a positive effect on educational outcomes. Gupta et al. (1999) underscored the fact that as household incomes rise, the relative cost of enrolling children into school is reduced, suggesting that increasing income would be associated with rising enrolments. In individual economic terms, literacy also has payoffs and it is a worthwhile investment. This, by implication, will improve literacy rate in the long run. In addition, at higher income levels, the demand for education would increase, assuming education is a normal good. The choice of adult literacy rate as a proxy for educational outcome is also supported by Gupta et al. (1999). Schady (2002) has shown that macroeconomic crisis affect education outcomes. The total effect of a crisis on educational attainment depends on the relative magnitude of the changes in the marginal costs and benefits from education. It is instructive to note that many variables have been used in literature to gauge macroeconomic instability. These include inflation rates, variability of real exchange rates, real interest rates, fiscal deficits terms of trade and external debt (Olaniyan, 2000). Macroeconomic uncertainty, derived by percentage change in annual inflation rate is employed in this study, where inflation rate is based on the consumer price index. This variable has been used as proxy for macroeconomic uncertainty due to non-availability of appropriate data. Urbanization is expected to have a positive impact on educational attainment. Since access to education is better in urban areas than in rural areas, urban dwellers will likely send their children to school. The inclusion of the variable in the model is supported by earlier literature review. 
Assuming a linear relationship between the dependent and the independent variables, equation (2) can be written as follows:

$$
L I T_{t}=\alpha_{0}+\alpha_{1} P E X_{t}+\alpha_{2} M A U_{t}+\alpha_{3} P C I_{t}+\alpha_{4} U R B_{t}+U
$$

where PCI and MAU are the variables in log form while others are at their respective levels. From the discussion in the previous section, the a priori expectations are: $\alpha_{1>0}, \alpha_{2<0}, \alpha_{3>0}, \alpha_{4,>0}$

The scope of the study covers the period between 1975 and 2007. These are the years for which all the data are available. All the time series data employed were sourced from the Central Bank of Nigeria (CBN) publications such as Annual Report and Statement of Account, and augmented by relevant publications of the National Bureau of Statistics (NBS) and the International Monetary Fund (IMF).

\section{Estimation techniques}

Most time series variables are non- stationary. The first or second differenced terms of most variables will usually be stationary (Adam, 1993; Perman, 1989). Therefore, the study, first, examines stochastic characteristics of each time series by testing their stationarity using Augmented Dickey Fuller (ADF) tests. Furthermore, cointegration test was carried out. The use of cointegration tests and error correction techniques has been widely acknowledged in empirical economics since their introduction over two decades ago. According to Komolafe (1996), two variables are said to be cointegrated if there exist a long run relationship between the dependent and independent variable. The cointegration arises out of the need to integrate short run dynamics with long run equilibrium between economic variables. The cointegration test was done employing Johansen (1988) framework by comparing the likelihood ratios against their critical values at five percent. If the various test performed support the fact that cointegrating relationships exist between the dependent and any (or a combination) of its explanatory variables, then there will be the need to estimate a parsimonious error correction model (ECM). The ECM is then employed to analyze the response of educational/schooling outcomes to a stimulus in the explanatory variables in a dynamic setting. The ECM is accepted when the residuals from the linear combination of non-stationarity I (I) series are themselves stationary. The acceptance of ECM implies that the model is best specified in the first difference of its variables. Consequently, the application of cointegration paradigm will guard against the loss of information from long-term relationships in the first differences (Azeez \& Falusi, 2003).

On intuitive ground, the modeling of educational outcomes equation in this study also uses the vector autogression (VAR) technique. VARs are useful for forecasting systems of interrelated time series variables. A VAR is explicitly formulated as a coherent unified system, with the variables chosen based on how they fit into the system as a whole rather than how they contribute to a particular sub-system. The problems created by exogeneity assumptions are provided by treating all variables as endogenous. Expectations are explicitly handled by allowing lags of every variable to enter the equation explaining each variable. Thus, the effects of the sequence of past states of the entire system on expectations, and therefore on the current value of a given variable, are accounted for in a reduced form. A VAR system is a system in which every equation has the same right hand variable, and those variables include lagged values of all the endogenous variables. VARs are also used for analyzing the dynamic impact of different types of random disturbances on systems of variables.

The estimated coefficients of the VARs are difficult to interpret. To draw conclusions about VAR, we are most interested in the variance decompositions and impulse response functions. What the VAR does is to express the residuals (or innovations) in terms of the variables in the model - the contemporaneous effects, i.e., invert the system. We can then generate innovations after decomposition, which have different economic interpretation. Thus, what is interesting in a VAR analysis is: (i) the impulse response functions: if the system is shocked by one unit of $\mathrm{x}$, how is $\mathrm{y}$ supposed to respond? This is traced out by impulse 
response functions. Consequently, the impulse response function describes the response of an endogenous variable to one of the innovations. Specifically, it traces the effects on current and future values of the endogenous variable of a one standard deviation shock to one of the innovations (Chete, 2001). (ii) Variance decomposition: in a VAR, the variance decomposition at horizon $h$ is the set of $R^{2}$ values associated with the dependent variable $y_{t}$ and each of the shocks $h$ periods prior. (iii) The forecast error variance: the variance of the series is decomposed into parts attributable to each set of the innovation (shock) process.

\section{EMPIRICAL FINDINGS}

Table 3 presents the results of the unit root tests. The ADF statistics were compared with the Mackinnon (1991) critical values provided by the Eviews econometrics. The results of the unit root test show that all the variables have unit roots, i.e. they are not stationary at levels but are stationary at first difference. This, by implication, means that schooling/educational outcome proxied by adult literacy rate (LIT), public educational expenditure as a percentage of GDP (PEX), per capita income (LPCI), macroeconomic uncertainty (MAU), urbanization (LURB) are all stationary at first difference.

The long-term relationships among the variables were examined using Johansen cointegration framework. The results of the cointegration test are reported on Table 4. The contegration test results indicate that there are four cointegration vectors that exist. In summary, the cointegration test showed that schooling/educational outcome proxied by adult literacy rate, per capita income, urbanization, macroeconomic uncertainty and public educational spending have equilibrium condition that keeps them in proportion to each other in the long run.

Table 3.

Result of Unit Root Tests Using Augmented Dickey Fuller (ADF)

\begin{tabular}{lccccc}
\hline \multirow{2}{*}{ Variable } & \multicolumn{2}{c}{ ADF Test Statistic } & \multicolumn{2}{c}{$95 \%$ ADF Critical Value } & \multirow{2}{*}{ Remarks } \\
\cline { 2 - 4 } & At Level & At $1^{\text {st }}$ Difference & At Level & At1 ${ }^{\text {st }}$ Difference & \\
\hline LIT & -1.7036 & -9.9819 & -3.5670 & -3.5614 & I(I) \\
PEX & -3.6629 & -4.7837 & $-3-5670$ & -3.5731 & I(I) \\
LPCI & -1.9219 & -5.8375 & -3.5670 & -3.5614 & I(I) \\
MAU & -3.3289 & -4.8266 & -3.5670 & -3.5731 & I(I) \\
LURB & -0.6562 & -4.2151 & -3.570 & -3.5731 & I(I) \\
\hline
\end{tabular}

Source: Extracted from the computer output.

Note: Series - LIT, LPCI, LURB, MAU, PEX LIT measures educational outcome proxied by adult literacy rate; PEX is public educational expenditure as a percentage of GDP; LPCI is the per capita income; MAU measures macroeconomic uncertainty; LURB measures urbanization.

Table 4.

Johansen Cointegration Tests Results

\begin{tabular}{ccccc}
\hline Eigen Value & $\begin{array}{c}\text { Likelihood } \\
\text { Ratio }\end{array}$ & $\begin{array}{c}\text { 5 Percent Critical } \\
\text { Value }\end{array}$ & $\begin{array}{c}\text { 1 Percent Critical } \\
\text { Value }\end{array}$ & $\begin{array}{c}\text { Hypothesized No } \\
\text { of CE(S) }\end{array}$ \\
\hline 0.742744 & 110.9470 & 76.07 & 84.45 & None ** \\
0.579669 & 68.8589 & 53.12 & 60.16 & At most $1 * *$ \\
0.466105 & 41.99072 & 34.91 & 41.07 & At most $2 * *$ \\
0.405282 & 22.53649 & 19.96 & 24.60 & At most $3 *$ \\
0.187237 & 6.426788 & 9.24 & 12.97 & At most 4 \\
\hline
\end{tabular}

Source: Extracted from the Computer Output

Note: Series - LIT, LPCI, LURB, MAU, PEX

Variables are as defined in Table 3.

$*(* *)$ denotes rejection of the hypothesis at $5 \%(1 \%)$ significance level.

L.R. test indicates 4 cointegrating equations(s) at $5 \%$ significance level. 
Table 5 shows the estimated results of the model. All the coefficients of the variables have the expected signs. Most of the coefficients are significant at the conventional level. In terms of the good fit of the model, the adjusted $\mathrm{R}^{2}$ is modest, implying that changes in adult literacy rate (dependent variable) can be satisfactorily explained by the explanatory variables included in the model. With respect to per capita income, a positive but not a significant relationship was established. This implies that per capita income has not been efficiently utilized to improve educational attainment in Nigeria.

The majority of citizens has low per capita income and this is not enough to encourage schooling. Even, as household incomes rise, the resources are channeled towards unproductive ventures not relating to educational development. This underscores the fact that sustainable per capita income is a necessary condition for enhancing social outcomes and successive Nigerian governments must create employment opportunities in order to enhance the earning capability of the people. Urbanization seems to be significant in explaining changes in educational attainment proxied by adult literacy rate. It is significant at 5 percent level. The coefficient appears to show a stronger level of significance when lagged by two years. The result suggests that urban dwellers encourage their children to go to school. Urbanization exposes a lot to appreciate the importance of education.
This may further reinforce the argument to develop the rural areas where more than sixty percent of the population is found. The results definitely strengthen the argument for massive investment in the education sector in both rural and urban areas. Considerable efforts must be put in place to woo stakeholders in the Nigerian economy to invest in the educational sector.

The coefficient of macroeconomic uncertainty has a negative but significant relationship impact on education/schooling outcome. The coefficient is significant at $1 \%$ when lagged by three years. This is not surprising: improvement of standards of living and sustainable growth requires sustainable policies.

Macroeconomic stability does not by itself ensure social progress or lead to economic development. It is a pre-requisite for sustainable growth and makes it easier to achieve societal objectives. Thus, any serious effort to improve literacy in Nigeria should be preceded by a sound macroeconomic framework of economic management.

The coefficient of public educational expenditure has a positive and significant relationship impact on education outcome proxied by literacy rate. It is significant at $1 \%$ level. This empirical evidence supports the argument that the role of public investment in human

Table 5.

Parsimonious Representation of the Error Correction Model Dependent Variable - D (LIT)

\begin{tabular}{lcccc}
\hline Variables & Coefficient & Std. Error & t-Statistic & Prob. \\
\hline Constant & -0.7176 & 0.7771 & -0.9234 & 0.3663 \\
D(LPCI(-3)) & 1.0027 & 3.3047 & 0.3034 & 0.7646 \\
D(LURB(-2)) & $27.9425^{* *}$ & 13.0638 & 2.1389 & 0.0443 \\
D(LMAU(-2)) & -0.0003 & 0.0002 & -1.4173 & 0.1711 \\
D(LMAU(-3)) & $-0.0005^{* * *}$ & 0.0002 & -2.7357 & 0.0124 \\
D(LPEX(-1)) & $0.8151^{* * *}$ & 0.1941 & 4.2000 & 0.0004 \\
D(LPEX(-2)) & $0.8361^{* * *}$ & 0.2676 & 3.1240 & 0.0051 \\
ECM(-1) & $-0.3948^{* *}$ & 0.1713 & -2.3051 & 0.3663 \\
\hline
\end{tabular}

Note: ***** means significant at $5 \%, 1 \%$, respectively

R-Squared $\quad 0.61$

Adjusted R-squared $\quad 0.48$

Durbin-Watson Stat 1.73

$\begin{array}{ll}\text { F-Statistic } & 4.66\end{array}$

Prob(F-Statistic) $\quad 0.00$

Source: Extracted from the Computer Output 
capital development cannot be overemphasized in a developing nation like, Nigeria. For rapid economic and sustainable economic progress, investment in education should be regarded as very important. Public intervention in education can lead to improvement in living standards, enabling equitable distribution of wealth and help reduce poverty incidence. The ECM is negative $(-0.39)$ as expected and significant at $5 \%$ level of significance. It shows that $39 \%$ disequilibria in adult literacy rates in previous year are corrected in the current year, that is, it shows that the variables have to be adjusted approximately by $39 \%$ to restore equilibrium in the short run.

An examination of the short-run dynamic properties of schooling outcome is further investigated by estimating forecast error variance decomposition and generalized impulse response analysis. Forecast error variance decomposition gives information on the dynamic behavior of the variables in the system. The variance decomposition shows the proportion of the error forecast variance for each variable attributable to its own innovation and to innovations in the other endogenous variables. In this case, it provides information on the importance of various structural shocks explaining the forecast variability of schooling outcome and its determinants. Table 6 presents the forecast error variance decomposition of the five endogenous variables. "Own shocks" variation ranged from $83.5 \%$ to $100 \%$ over the ten-year horizon. From a contribution of $100 \%$ to variations in its forecast errors, the contribution of adult literacy rate fell to $89.4 \%$ in the medium term and $83.5 \%$ in the long term. The lost share was taken up by other variables. The innovation of macroeconomic uncertainty which accounts for the forecast error variance of literacy rate ranged from $0 \%$ to $2.91 \%$. In summary, the variance decomposition analysis shows that "own shocks" constitute the predominant source of variation in schooling outcome.

Table 7 and Figure 3 show the results of the impulse response analyses derived from the estimated VAR models. The impulse response functions are tools to show the dynamics of the variables tracing out the reaction of each variable to a particular shock at time $t$. One can conclude from the findings in Table 7 that past schooling outcome (proxied by adult literacy rates) shocks have positive but declining relationship with current adult literacy rate in the first nine years, and the relationship turns negative in the tenth year. Any unanticipated increase in the macroeconomic uncertainty rate will have a contractionary impact on the adult literacy rate.

Table 6.

Variance decomposition of Adult literacy rate (LIT)

\begin{tabular}{ccccccc}
\hline Period & S.E. & LIT & LPCI & LURB & MAU & PEX \\
\hline 1 & 1.473182 & 100.0000 & 0.000000 & 0.000000 & 0.000000 & 0.000000 \\
2 & 1.544475 & 98.29627 & 0.479502 & 0.002232 & 1.174930 & 0.047070 \\
3 & 1.841541 & 94.31599 & 2.458247 & 0.232155 & 2.585811 & 0.407798 \\
4 & 1.937486 & 91.94437 & 4.427196 & 0.341142 & 2.590844 & 0.696446 \\
5 & 2.042247 & 89.35966 & 5.994876 & 0.853463 & 2.838509 & 0.953496 \\
6 & 2.083242 & 87.54826 & 7.000586 & 1.438195 & 2.910288 & 1.102666 \\
7 & 2.110906 & 86.16688 & 7.487892 & 2.255696 & 2.898293 & 1.191240 \\
8 & 2.124757 & 85.15321 & 7.616410 & 3.137965 & 2.869184 & 1.223229 \\
9 & 2.136080 & 84.26696 & 7.578333 & 4.090695 & 2.839003 & 1.225004 \\
10 & 2.146376 & 83.46551 & 7.506245 & 4.997709 & 2.815998 & 1.214538 \\
\hline
\end{tabular}

Source: Extracted from the Computer Output 
Table 7.

Impulse Response Functions. Response of LIT to One S.D. Innovations

\begin{tabular}{|c|c|c|c|c|c|}
\hline Period & LIT & LPCI & LURB & MAU & PEX \\
\hline \multirow[t]{2}{*}{1} & 1.473182 & 0.000000 & 0.000000 & 0.000000 & 0.000000 \\
\hline & $(0.18709)$ & $(0.00000)$ & $(0.00000)$ & $(0.00000)$ & $(0.00000)$ \\
\hline \multirow[t]{2}{*}{2} & 0.417729 & 0.106949 & 0.007297 & -0.167412 & -0.033508 \\
\hline & $(0.25245)$ & $(0.23116)$ & $(0.22271)$ & $(0.25745)$ & $(0.23188)$ \\
\hline \multirow[t]{2}{*}{3} & 0.923986 & 0.268194 & 0.088429 & -0.244264 & 0.112724 \\
\hline & $(0.28431)$ & $(0.18155)$ & $(0.11529)$ & $(0.25504)$ & $(0.18207)$ \\
\hline \multirow[t]{2}{*}{4} & 0.502936 & 0.287793 & 0.070235 & -0.097799 & 0.110969 \\
\hline & $(0.28343)$ & $(0.23387)$ & $(0.16521)$ & $(0.15818)$ & $(0.15257)$ \\
\hline \multirow[t]{2}{*}{5} & 0.524912 & 0.289555 & 0.150964 & -0.145366 & 0.116725 \\
\hline & $(0.30121)$ & $(0.23649)$ & (0.08919) & $(0.16504)$ & $(0.13652)$ \\
\hline \multirow[t]{2}{*}{6} & 0.269290 & 0.231917 & 0.163769 & -0.088971 & 0.089925 \\
\hline & $(0.28526)$ & $(0.23312)$ & $(0.10153)$ & $(0.12911)$ & $(0.11525)$ \\
\hline \multirow[t]{2}{*}{7} & 0.200064 & 0.172733 & 0.195182 & -0.053312 & 0.072292 \\
\hline & $(0.28625)$ & $(0.20828)$ & $(0.07526)$ & $(0.10850)$ & $(0.09758)$ \\
\hline \multirow[t]{2}{*}{8} & 0.069211 & 0.100971 & 0.202865 & -0.019653 & 0.046293 \\
\hline & $(0.27358)$ & $(0.17860)$ & $(0.07544)$ & $(0.08805)$ & $(0.07563)$ \\
\hline \multirow[t]{2}{*}{9} & 0.025328 & 0.044011 & 0.212097 & -0.002654 & 0.025906 \\
\hline & $(0.26489)$ & $(0.15058)$ & $(0.06931)$ & $(0.07863)$ & $(0.06316)$ \\
\hline \multirow[t]{2}{*}{10} & -0.015332 & -0.004540 & 0.208781 & 0.013857 & 0.007614 \\
\hline & $(0.25212)$ & $(0.13296)$ & $(0.06658)$ & $(0.07248)$ & $(0.05483)$ \\
\hline
\end{tabular}

Source: Extracted from the Computer Output

\section{CONCLUDING REMARKS}

This study investigated the effect of government educational spending and macroeconomic uncertainty on schooling outcomes in Nigeria for the period from 1975 to 2007, using econometric methods of cointegration and error correction mechanism together with the vector auto-regression methodology. The study examines the stochastic characteristics of each time series by testing their stationarity us ${ }^{\mathrm{o}}$ ocks of each of the endogenous variables are examined, using Vector Autoregressive (VAR) model. The cointegration analysis showed that schooling/educational outcome proxied by adult literacy rate, per capita income, urbanization, macroeconomic uncertainty and public educational spending have equilibrium condition that keeps them in proportion to each other in the long run, at least in the Nigerian context.

Econometric estimations show a positive and significant relationship between government educational spending and educational/schooling outcome. Macroeco- nomic instability affects schooling outcomes negatively in Nigeria. The variance decomposition analysis shows that "own shocks" constitute the predominant source of variation in schooling outcome. The impulse response analysis shows that any unanticipated increase in the macroeconomic uncertainty rate will have a contractionary impact on the adult literacy rate.

The policy implication of this study is that government should pay attention to policies that enhance educational attainment through adequate public social investment under stable macroeconomic environment. Successive Nigerian governments must give top priority to education financing. A situation where the country spends an insignificant proportion of total government expenditure and gross domestic product on education leaves much to be desired. As a matter of urgency, government should massively invest in education. Within this context attention should be given to the need to provide educational facilities which makes learning practical and easier. 
Response of One S. D. Innovations \pm 2 S. E.
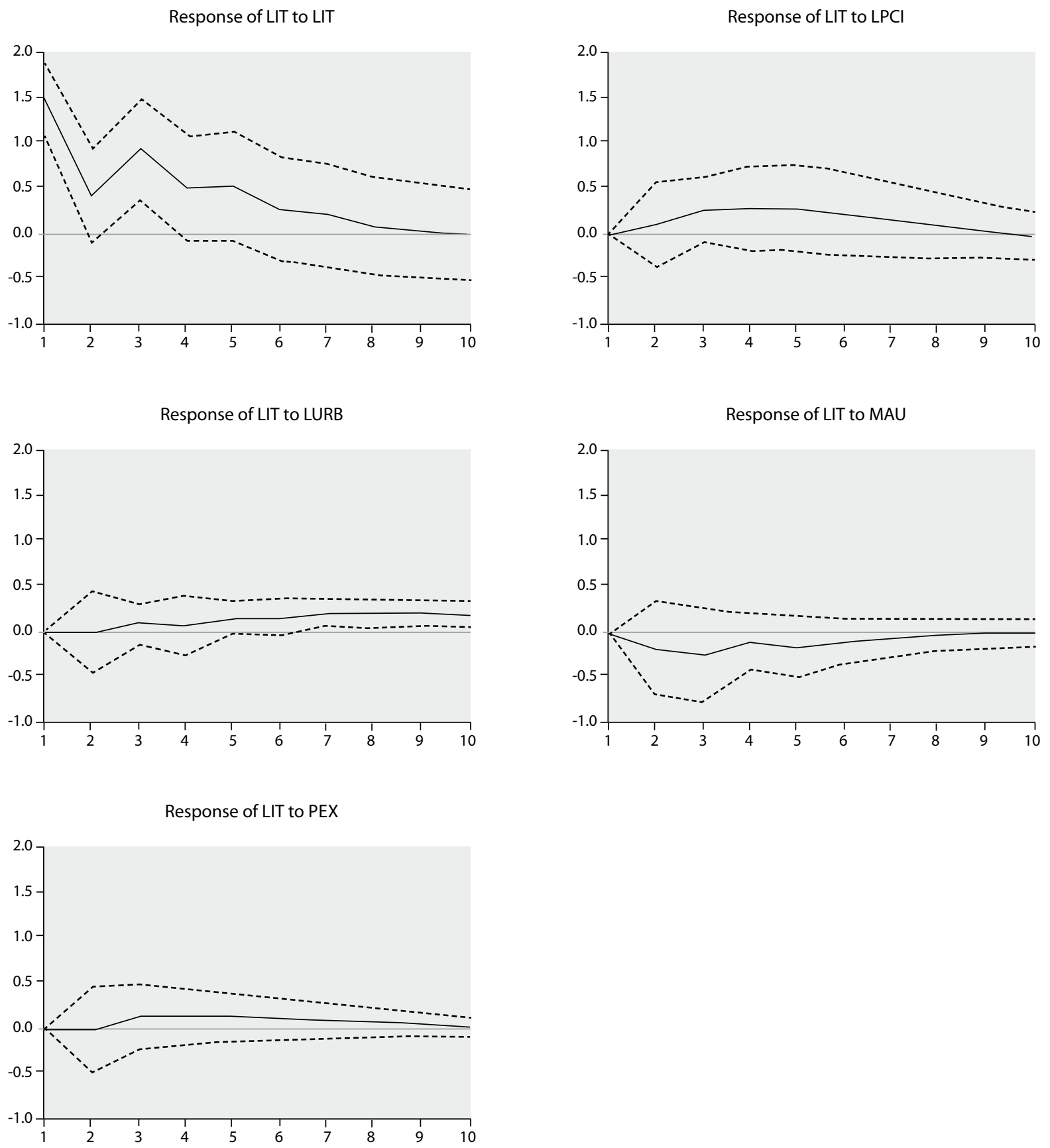

Figure 3. Generalized Impulse Response(s) to One Shock in the equation for Adult literacy rate to one shock in explanatory variables. 


\section{References}

Adam, C. S. (1993). Time Series Econometrics in Africa. Lecture notes for a technical workshop run by AERC, Nairobi, Kenya.

Anand, S., \& Ravallion, M. (1993). Human Development in Poor Countries: On the Role of Public Services. Journal of Economics Perspectives, 7(1), 135-50.

Anyanwu, J. C., \& Erhijakpor, A. E. O. (2007). Education Expenditures and School enrolment in Africa: illustrations from Nigeria and the other SAWE Countries. Paper presented at the $50^{\text {th }}$ Anniversary and Annual Conference of the Nigerian Economic Society, Abuja, Nigeria.

Azees, A. A., \& Falusi, A. O. (2003). Rice Import Model for Nigeria: A Case for Self-Sufficiency. The Nigerian Journal of Economic and Social Studies, 45(3), 199-211.

Baldacci., E., Guin-Sui, M. T., \& de Mello, L. (2004). More on the Effectiveness of Public Spending on Healthcare and Education: A Covariance Structure Model Journal of International Development, 15(6), 709 725 .

Barro, R. J. (1998). Human Capital and Growth in CrossCountry Regressions. Technical Report Mimeo. Harvard University.

Barro R. J., \& Sala-i-Martin, X. (1995). Economic Growth. New York: MacGraw-Hill.

Basu, K., \& Van, P. H. (1998). The Economics of Child Labor. The American Economic Review, 88(3), 412-27.

Behrman, J. R., Duryea, S., \& Szekely, M. (2000). Schooling Investments and Aggregate Conditions. A Household-Survey-Based Approach for Latin America and the Caribbean. Unpublished manuscript, InterAmerican Development Bank.

Cameron, L. (2000). The Impact of the Indonesian Financial Crisis on Children: An Analysis Using the 100 Villages Data. Unpublished manuscript, University of Melbourne, Australia.

Central Bank of Nigeria (2008). Annual Report and Statement of Accounts. Abuja, Nigeria: Author.
Central Bank of Nigeria (2005). Statistical Bulletin. Abuja, Nigeria: Author.

Chete, L. N. (2001). Explaining Current Account Behavior in Nigeria. The Nigerian Journal of Economic and Social Studies, 43(2), 219-238.

Colclough, C., \& Lewin, K. (1993): Educating all the Children: Strategies for Primary Schooling in the South. Oxford: Clarendon Press.

Filmer, D., \& Prichett, L. (1997). Child Mortality and Public Spending on Health: How Much does Money Matter? (World Bank Policy Research Working Paper No. 1864). Washington, D. C.: World Bank.

Flug, K., Spilimbergo, A., \& Wachtenheim, E. (1998). Investments in Education: Do Economic Volatility and Credit Constraints Matter? Journal of Development Economics, 55, 465-81.

Galor, O., \& Zeira, J. (1993). Income Distribution and Macroeconomics. Review of Economic Studies, 60(1), 35-52.

Goldin, C. (1999). Egalitarianism and the Returns to Education during the Great Transformation of American Education. Journal of Political Economy, 107(6), S65-S94.

Gupta, S., Verhoeven, M., \& Tiongsan, E. (2002). The Effectiveness of Government Spending on Education and Health Care in Developing and Transition Economics. European Journal of Political Economy, 18(4), 717-737.

Gupta, S., Verhoeven, M., \& Tiongsan, E. (1999). Does Higher Spending Buy Better Results in Education and Health Care? (IMF Working Paper WP/99/21) Washington, D. C.: International Monetary Fund.

Harbison, R., \& Hanushek, E. (1992). Educational Performance of the Poor, Lessons from Rural Northeast Brazil. New York: Oxford University Press.

Hill, M. A., \& King, E. M. (1991). Women Education in the Third World: An overview. In E. M. King \& M. A. Hills (Eds.) Women Education in Developing 
Countries: Barriers, Benefits and Policy. Washington, D. C.: The World Bank.

Johansen, S. (1988). Statistics Analysis of Cointegration Vectors. Journal of Economic Dynamics and Control, 12(3), 231-254.

Kisswani, K. (2008). Did the Great Depression affect Educational Attainment in the US? Economic Bulletin, 9(30), 1-10.

Komolafe, O. S. (1996). Cointegration Theory: Technique and Application. In I. M Obadan \& M. A. Iyoha (Eds.), Macroeconomic Policy Analysis: Tools, Techniques and Application to Nigeria. Ibadan, Nigeria: NCEMA.

Mackinnon, J. G. (1991). Critical Values for Cointegration Tests. In R. F. Engle \& C. W. J. Granger (Eds.) Long-run Economic Relationships: Readings in Cointegration (Chapter 13). New York: Oxford University Press.

McMahon, W. (1999) Education and Development; Measuring the Social Benefits. New York: Oxford University Press.

Mingat, A., \& Tan, J. P. (1992). Education in Asia: A Comparative Study of Cost and Financing. Washington, D. C.: World Bank.

Moock, P. R., \& Jamison, D. T. (1988). Educational Development in Sub-Saharan African. Finance and Development, 25(1), 22-24.

Mukherjee, A. N. (2007). Public Expenditure on Education: A Review of Selected Issues and Evidence. <http:// www.nipfp.org.in/working-paper/wp_2007_hd_51. pdf $>$.

Musgrave, R. A., \& Musgrave, P. B. (1989). Public Finance in Theory and Practice. $5^{\text {th }}$ Edition. New York: McGraw-Hill International Editions, Finance Series.

National Bureau of Statistics (2007). Annual Abstract of Statistics, Abuja, Nigeria: Federal Government of Nigeria.

National Planning Commission (2004). National Economic Empowerment and Development Strategy. Abuja, Nigeria: Author.
Noss, A. (1991). Education and Adjustment: A Review of the Literature. (PREM Working Paper WPS 701). Washington, D. C.: World Bank.

Ogbu, O. M., \& Gallagher, M. (1991). Public Expenditures and Health Care in Africa. Social Science and Medicine, 34(6), 615-624.

Olaniyan, O. (2000). The Effect of Economic Stability on Aggregate Investment in Nigeria. The Nigerian Journal of Economic and Social Studies, 42(1), 23-36.

Onwioduokit E. A., \& Tule, M. K. (2002). Options for Sustainable Funding of Education in Nigeria. In Ozoesan, \& G. Evbuomwan (Eds.) Human Resources Development in Africa. Conference Proceedings of the Nigerian Economic Society (pp. 523-550). Ibadan, Nigeria.

Perman, R. (1989). Cointegration; An introduction to the literature. Strathclyde Papers In. Economics, 89/7.

Pradhan, M., \& Sparrow, R. (2000). Basic Education Outcomes during Crisis: An Analysis Using the 1995, 1997, 1998, and 1999 SUSENAS. Unpublished manuscript. Washington, D. C.: World Bank.

Psacharopoulous, G. (1997). Child Labour versus Educational Attainment: Some Evidence from Latin America. Journal of Population Economics, 10(4), 377-86.

Schady, N. R. (2002). The (Positive) Effect of Macroeconomic Crises on the Schooling and Employment Decisions of Children in a Middle-Income Country (WB Policy Research Working Paper Series 2762). Development Research Group: The World Bank.

Sen, A. (1999). Development as Freedom. Oxford, UK: Oxford University Press.

UNDP. (2009). Human Development Report 2009. New York: Oxford University Press.

World Bank. (1980). World Development Report. Washington, D.C.: World Bank. 